\title{
Investigation of the Mechanism of Resistance to Glyphosate HeRbicide in HAIRY Fleabane ${ }^{1}$
}

\author{
Investigação do Mecanismo de Resistência de Buva ao Herbicida Glyphosate
}

KASPARY, T.E. ${ }^{2}$, LAMEGO, F.P. ${ }^{3}$, LANGARO, A.C. ${ }^{4}$, RUCHEL, Q. ${ }^{5}$, and AGOSTINETTO, D. ${ }^{5}$

\begin{abstract}
The resistance of weeds to herbicides is a consequence of one or more mechanisms in the plant, responsible for not allowing the herbicide to act properly at the active site. The objective of this study was to investigate the mechanism(s) of resistance to glyphosate in Conyza bonariensis. An experiment was conducted in November and December, 2012 and repeated in February and March, 2013 using a factorial arrangement of the treatments, where the factor A corresponded to biotypes of hairy fleabane, susceptible (S) and resistant (R); the factor B to seven rates of glyphosate from 0 to $11,520 \mathrm{~g}$ e.a. ha-1, and factor $\mathrm{C}$ were simulated environmental conditions of winter $\left(12 / 8{ }^{\circ} \mathrm{C}\right.$ day/night of temperature and $10 / 14 \mathrm{~h}$ of photoperiod) and summer $\left(28 / 20{ }^{\circ} \mathrm{C}\right.$ day/night of temperature and $14 / 10 \mathrm{~h}$ of photoperiod). An assay evaluating the shikimic acid was performed twice in the month of July 2013, with treatments arranged in a factorial arrangement, being factor A biotypes of hairy fleabane, $\mathrm{S}$ and $\mathrm{R}$ and the factor $\mathrm{B}$ seven glyphosate rates $\left(0\right.$ to $28,8 \mathrm{mg}$ a.e. $\left.\mathrm{L}^{-1}\right)$. The $\mathrm{R}$ biotype of C. bonariensis does not appear to present the sequestration of herbicide in the vacuole as the mechanism of resistance. However, the low accumulation of shikimate by the $\mathrm{R}$ biotype characterizes lower sensitivity of EPSPs enzyme to glyphosate, inferring that this is the present mechanism of resistance in plants of $C$. bonariensis. However, the resistance cannot be associated to a unique mechanism of resistance, requiring further studies to its understanding.
\end{abstract}

Keywords: Conyza bonariensis, temperature, photoperiod, EPSPs.

\begin{abstract}
RESUMO - A resistência de plantas daninhas aos herbicidas é consequência da ocorrência de um ou mais mecanismos na planta, responsáveis por não deixarem o herbicida atuar de forma eficiente sobre o local de ação. O objetivo deste estudo foi investigar o(s) mecanismo(s) de resistência em Conyza bonariensis ao herbicida glyphosate. Um experimento foi conduzido de novembro a dezembro de 2012 e repetido em fevereiro e março de 2013, com arranjo fatorial, em que ofator A correspondeu aos biótipos de buva suscetivel (S) e resistente (R); o fator $B$, a sete doses de glyphosate, que variaram de 0 a $11.520 \mathrm{~g} \mathrm{e.a.} \mathrm{ha-1}$; e o fator $C$ às condições que simularam o inverno (temperatura de $12 / 8{ }^{\circ} \mathrm{C}$ dia/noite e fotoperiodo de $10 / 14$ horas) e verão (temperatura de $28 / 20^{\circ} \mathrm{C}$ dia/ noite $e$ fotoperiodo de 14/ 10 horas). Um ensaio que avaliou o acúmulo de shiquimato foi realizado duas vezes no mês de julho de 2013, com tratamentos dispostos em esquema fatorial, sendo o fator A os biótipos de buva, S e R, e o fator $B$, sete doses de glyphosate (O a 28,8 mg e.a. $\left.L^{-1}\right)$. O biótipo R de C. bonariensis aparenta não apresentar o mecanismo de sequestro do herbicida no vacúolo como mecanismo de resistência. Entretanto, o menor acúmulo de shiquimato pelas plantas do biótipo $R$ caracteriza a menor sensibilidade da enzima EPSPS ao glyphosate, inferindo que esse seja o mecanismo de resistência presente em plantas de C. bonariensis. Contudo, a resistência pode não estar atrelada a apenas um mecanismo de resistência, exigindo, para seu inteiro entendimento, estudos complementares.
\end{abstract}

Palavras-chave: Conyza bonariensis, temperatura, fotoperíodo, EPSPs.

Recebido para publicação em 12.7.2015 e aprovado em 26.2.2016.

2 Universidade Federal do Rio Grande do Sul, Porto Alegre-RS, Brasil, <tiago_kaspary@yahoo.com.br >; ${ }^{3}$ Embrapa Pecuária Sul CPPSul, Bagé-RS, Brasil; ${ }^{4}$ Universidade Federal de Viçosa, Viçosa-MG, Brasil; ${ }^{5}$ Universidade Federal de Pelotas, Pelotas-RS, Brasil 


\section{INTRODUCTION}

The glyphosate, enolpyruvylshikimate phosphate synthase (EPSPs) inhibitor herbicide, consisted, until not long ago, in the main control form for the hairy fleabane (Conyza bonariensis), one of the major weeds on agricultural areas grown in the Spring/ Summer period of the central-south region in Brazil, especially in soy crops. The massive use of this herbicide molecule in the soy's drying previously to the seeding and in postemergency of transgenic crops resistant to this herbicide, associated to a high capacity of seed production in this species, contributed in raising the selective pressure over the hairy fleabane, culminating in the evolution of resistant biotypes.

Weed resistance to herbicides is defined by FAO as the natural occurrence of biotypes with the ability to survive to the use of a chemical compound which the original population was susceptible (Lebaron and Gressel, 1982). This skill of surviving herbicides is associated with one or more resistance mechanisms, responsible for not letting the herbicide act in an efficient manner over the active site in plants, that is, the EPSPs enzyme. The mechanisms related to glyphosate are known only for 11 species from the total of resistant plants, and they can be divided in two groups: those that involve interactions in the active site and those not related to the target area of action of the herbicide (Powles and Yu, 2010). Mutations in the gene that encodes the EPSPs enzyme and the increase in this gene's amplification are examples of resistance mechanisms related to the active site, while the reduced absorption, translocation and the sequestration of the herbicide by the vacuole are examples of mechanisms not directly related to the active site (Powles and $\mathrm{Yu}, 2010)$.

The most common mechanisms reported to glyphosate resistance have been the reduced absorption and translocation of the product. The reduced translocation is mentioned by Ferreira et al. (2008) as a resistance mechanism in biotype of $C$. bonariensis in Brazil. A greater accumulation of the herbicide has been observed in the resistant biotype's treated leaf, while in the susceptible biotype the greater accumulation was found in the aerial part (leaves and stem) and in the roots, indicating a reduced translocation by the resistant. The same mechanism is responsible for the resistance to glyphosate in C. canadensis (Feng et al., 2004), Lolium multiflorum (Nandula et al., 2008) and L. rigidum (Yu et al., 2009).

In C. canadensis, it was observed the sequestration of the herbicide glyphosate in the resistant biotypes' vacuoles (Ge et al., 2010). The sequestration occurred due to an increase in the transference rate of the herbicide from the chloroplast to the vacuole, performed, possibly, by the greater expression of a non-identified molecular carrier. In another study with $C$. canadensis biotype, resistant to glyphosate, a reversive effect was verified in low temperatures over the display of resistance by vacuole sequestration (Ge et al., 2011). According to these authors, when the resistant biotype is exposed to temperatures between 20 and $30{ }^{\circ} \mathrm{C}$, the sequestration reaction of the herbicide by the cell's vacuole is accelerated, inhibiting its action over the EPSPs enzyme, and, consequently, the resistance occurs. However, under low temperatures $\left(8-10^{\circ} \mathrm{C}\right)$, a reversal of the resistance occurred, resulting in a lower activity of the possible carriers responsible for the sequestration of herbicide by the vacuole, and the plant behaves as susceptible.

The evaluation of the accumulation of shikimic acid from tests with leaf discs was shown as a promising and fast method to detect glyphosate resistance in Conyza and other plant species (Koger et al., 2005; Shaner et al., 2005). This is due to the fact that shikimate accumulates in the plant tissues after the treatment with glyphosate, and the amounts accumulated are usually bigger in the susceptible biotype than in resistant plants (Henry et al., 2007; Mueller et al., 2008).

Understanding the resistance mechanism to glyphosate in weeds is necessary to ensure the continuity of the herbicide's use (Service, 2007). In Brazil, except by the study done by Ferreira et al. (2008), there are no reports of elucidation of the resistance mechanism in 
C. bonariensis. Thereby, the identification of the resistance mechanism will result in opportune changes in this weed management and in the propagation of the glyphosate resistance. In this context, the objective of this study was to investigate the resistance mechanism to glyphosate in resistant biotype of $C$. bonariensis, through analysis based in the action site of the herbicide (EPSPs enzyme) and in those not related to the active site.

\section{MATERIAL E METHODS}

This study was divided in two stages: the investigation of the resistance mechanism not related to the active site and the resistance mechanism related to the active site.

\section{Resistance Mechanism - not related to the active site}

The study was conducted from November to December, 2012, being repeated from March to April, 2013, in BOD growth chambers, in the Laboratorio de Tecnologia de Sementes (Seed Technology Laboratory) in the Federal University of Santa Maria - UFSM, Frederico Westphalen campus, Rio Grande do Sul. The resistant biotype (R), was native from Jaboticaba-RS $\left(27^{\circ} 40^{\prime} 30.18^{\prime \prime} \mathrm{S}\right.$ e $53^{\circ} 17^{\prime} 51.12$ " O), with the glyphosate resistance being confirmed in a preliminary study (data not shown). The susceptible biotype (S), was native from Frederico Westphalen-RS (27²3’46.31" S e 5325’39.50" O). The seeds of both biotypes were collected previously from the respective populations $\mathrm{S}$ and $\mathrm{R}$. The identification of the species as Conyza bonariensis was done through the analysis of a complete exsiccate sent to the Instituto de Biociências (Bioscience Institute) in the Botanic Department in the Federal University of Rio Grande do Sul (UFRGS), Porto Alegre, Rio Grande do Sul.

The trial design was entirely randomized, with the treatments disposed in a factorial diagram $2 \times 7 \times 2$, in which the A factor corresponded to the hairy fleabane's biotypes $\mathrm{S}$ and $\mathrm{R}$; the $\mathrm{B}$ factor referred to the glyphosate doses: 0, 45, 90, 180, 360, 720, 1.440 g e.a. ha ${ }^{-1}$, for the biotype S, e 0, 360, 720, 1,440, 2,880, 5,760 e 11,520 g e.a ha-1 ${ }^{-1}$ to the biotype R; and the $\mathrm{C}$ factor consisted in two temperature and photoperiod conditions, simulating winter (temperatures of $12 / 6{ }^{\circ} \mathrm{C}$ day/night and photoperiod of $10 / 14$ hours) and summer (temperature of $28 / 20^{\circ} \mathrm{C}$ and photoperiod of 14/10 hours), with three repetitions per treatment.

Hairy fleabane plants from both biotypes, $\mathrm{S}$ and $\mathrm{R}$, were obtained though seeding in substratum and, when they had 4-5 leaves, stored in a growth chamber, where they were kept for 10 days in the respective temperatures of winter and summer, for acclimatization. After this period, the plants (with 5-6 leaves) were taken of the growth chamber for treatment application. For this, costal pulverizer was used, pressured with $\mathrm{CO}_{2}$, with volume of $200 \mathrm{~L} \mathrm{ha}^{-1}$ and application bar equipped with four flat nozzles XR 110.02, with $0.5 \mathrm{~m}$ of distance between each. The applications were made in the beginning of the day, where the application conditions for the experiment conducted in November/12 was $19.5{ }^{\circ} \mathrm{C}$ of temperature and $76 \%$ relative humidity of the air (RH). In March/13, the temperature was of $17.3^{\circ} \mathrm{C}$ and $\mathrm{RH}$ of $81 \%$. Immediately after the application of the treatment, the plants were put in the respective growth chambers.

The control percentage (\%) was evaluated 21 and 42 days after applying the treatments (DAT), using a visual scale, where the total absence of control corresponded to the value 0 and the death of the plant, to the value $100 \%$. The dry mass from the aerial part was also evaluated to 42 DAT, and the vegetal material was collected and kept in the oven until it reached a constant weigh, in $70{ }^{\circ} \mathrm{C}$. The dry mass was corrected to percentages through comparison of the obtained mass in the treatment with herbicides with the mass of the control, considered 100\%.

The results from both experiments of response to the dose were submitted to variance analysis $(p \leq 0.05)$. When the interaction biotype $\mathrm{x}$ dose was observed, there was an adjustment to the sigmoidal equation of three parameters, with the help of the Sigma Plot software version 10.1:

$$
Y=a /\left(1+\exp \left(-\left(X-X a_{50}\right) / b\right)\right)
$$

Planta Daninha, Viçosa-MG, v. 34, n. 3, p. 555-564, 2016 
where $Y=$ dependent variable (control or dry mass), $X=$ independent variable (herbicide dose (g e.a. ha-1)); $a=$ difference between maximum and minimum; $b=$ curve declivity; and $X a_{50}=$ herbicide dose (g e.a. ha ${ }^{-1}$ ) responsible for reducing the dependent variable to the corresponding level of $50 \%$ from the maximum asymptote (a). The following coefficients were calculated by the equation: the value of $\mathrm{X}_{50}$, that is, the dose value responsible for causing $50 \%$ of control $\left(\mathrm{C}_{50}\right)$, or reducing $50 \%$ of the MSPA of the biotypes $\left(G R_{50}\right)$, and the resistance factor (FR), calculated through $\mathrm{C}_{50} \mathrm{R} / \mathrm{C}_{50} \mathrm{~S}$ e $\mathrm{GR}_{50} \mathrm{R} /$ $\mathrm{GR}_{50} \mathrm{~S}$.

\section{Resistance Mechanism - related to the active site}

A study evaluating the accumulation of shikimate by the biotypes was conducted in the Laboratory of CEHERB/PPGFs, Federal University of Pelotas - UFPel, and repeated in time (twice) in July, 2013. The trial design was entirely randomized, with the treatments disposed in a factorial diagram $2 \times 7$, in which the A factor corresponded to the biotypes of hairy fleabane $\mathrm{S}$ and $\mathrm{R}$; and the $\mathrm{B}$ factor referred to glyphosate doses: 0; 0.112; 0.226; $0.450 ; 0.900 ; 1,800$ and $3.600 \mathrm{mg}$ e.a. $\mathrm{L}^{-1}$, for the biotype $\mathrm{S}$, and $0 ; 1.8 ; 3.6 ; 7.2 ; 14.4$ and $28.8 \mathrm{mg}$ e.a. $\mathrm{L}^{-1}$, for the biotype R. A pure glyphosate active ingredient was utilized. The protocol was adapted from Nol et al. (2012). Plants of $C$. bonariensis with 5-6 leaves were used, pre-germinated and subsequently transplanted to plastic glasses, according to previous description, being kept in the vegetation house.

Leaf discs if $5 \mathrm{~mm}$ diameter were extracted manually from the hairy fleabane leaves, with the help of a metal extractor. The discs were put in Petri dishes, that contained $10 \mathrm{~mL}$ of ammonium phosphate solution $\left.\left(\left(\mathrm{NH}_{4}\right)_{2} \mathrm{HPO}_{4}\right)\right)$ in the concentration of 10 molar (M), $0.1 \%(\mathrm{v} / \mathrm{v})$ of surfactant Tween 80 and the referred treatments with glyphosate. Each Petri dish represented a repetition in the treatment, and each repetition was constituted of four hairy fleabane leaf discs. The dishes were sealed with plastic film to avoid the solution's evaporation, and incubated under fluorescent light (approximately $200 \mu \mathrm{ol} \mathrm{m} \mathrm{m}^{-2} \mathrm{~s}^{-1}$ ) in $26^{\circ} \mathrm{C}$, for 16 hours. Then, for each treatment and repetition separately, the discs were macerated with the help of liquid nitrogen and kept in Eppendorf tubes, of $1.25 \mathrm{M}$ in each tube. The samples were vigorously mixed for five minutes and incubated under agitation for 30 minutes, in $37^{\circ} \mathrm{C}$.

After the incubation, the samples were centrifuged at $12,000 \mathrm{rpm}$ for 10 minutes. Subsequently, two supernatant aliquots of $250 \mu \mathrm{L}$ were transfered to Eppendorf tubes, containing $1 \mathrm{~mL}$ of solution $0.25 \%$ of periodic acid and $0.25 \%$ of metaperiodic acid. The samples were incubated again at $37{ }^{\circ} \mathrm{C}$, for 60 minutes. After, it was added in each tube $1 \mathrm{~mL}$ of $\mathrm{HCl}$ solution $(0.6 \mathrm{M})$ and sodium sulfite $\left(\mathrm{Na}_{2} \mathrm{SO}_{3}[0,22 \mathrm{M}]\right)$. Then, a reading was made $(380 \mathrm{~nm})$ in spectrometer (Ultrospec 2100 Pro UV/Visible - Amersham Bioscience), and the values, adjusted to the linear equation, obtained from the standard curve of known doses of shikimate in hydrochloric acid $1.25 \mathrm{M}$.

The accumulation of shikimate in the hairy fleabane discs was obtained subtracting from the value acquired by the glyphosate treatments the control value (without the glyphosate). The average value of shikimate was submitted to variance analysis $(p \leq 0.05)$, and after the interaction biotype $\mathrm{x}$ dose was observed, adjustments were made in the sigmoidal equation:

$$
Y=a /\left(1+\exp \left(-\left(X-X a_{50}\right) / b\right)\right)
$$

where $Y=$ dependent variable (shikimate accumulation); $X=$ independent variable (herbicide dose (mg e.a. $\left.\mathrm{L}^{-1}\right)$ ); $a=$ difference between the maximum and minimum asymptote; $b=$ curve declivity; and $X a_{50}=$ herbicide dose (mg e.a. $\mathrm{L}^{-1}$ ) responsible for reducing the dependent variable to the corresponding level of $50 \%$ of the maximum asymptote $(a)$. The respective coefficients were calculated by the equation: the value of $X_{50}$, that is, the dose value responsible for increasing in 50\% the shikimate accumulation $\left(\mathrm{AS}_{50}\right)$, and the resistance factor (FR), calculated through $\mathrm{AS}_{50} \mathrm{R} / \mathrm{AS}_{50} \mathrm{~S}$. 


\section{RESULTS AND DISCUSSION}

The results will be presented according to the studies of the resistance mechanism.

\section{Resistance Mechanism - not related to the active site}

An interaction between biotype $\mathrm{x}$ herbicide dose $\mathrm{x}$ temperature and photoperiod conditions was observed. The visual control and dry mass data were adjusted to the sigmoidal curves of three parameters (Figure 1). The determination coefficient values $\left(\mathrm{R}^{2}\right)$ varied from 0.84 to 0.99 , showing a satisfactory adjustment from the data to the model (Table 1).

To the 21 DAT, in the winter condition, with low temperatures and reduced photoperiod, an increase in the visual control of both biotypes was observed, due to the increase of the herbicide dose (Figure 1A). However, biotype $\mathrm{S}$ showed a satisfactory



(B)

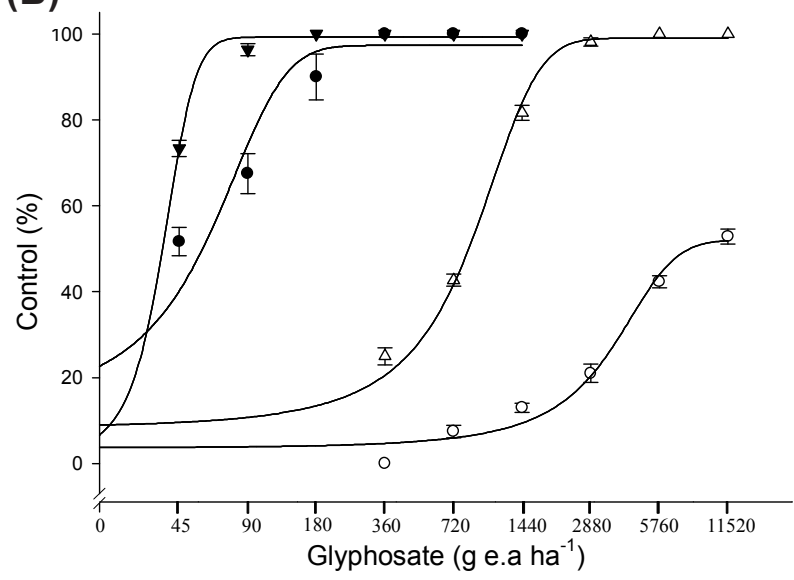

(C)

42 DAT

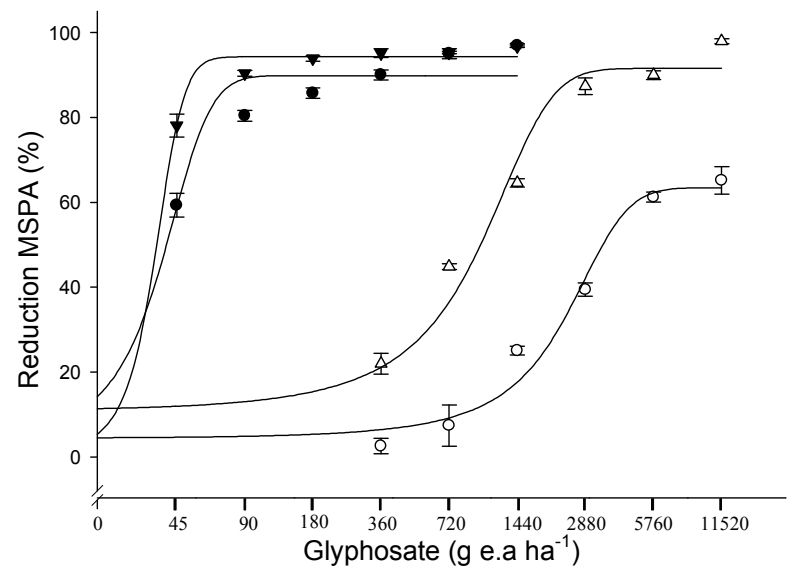

- Susceptible-Winter O Resistant-Winter

$\nabla$ Susceptible-Summer $\Delta$ Resistant-Summer

* The dots represent the average in the repetitions, and the vertical bars, the confidence interval.

Figure 1 - Controle (\%) of biotypes of Conyza bonariensis susceptible (S) and resistant (R) to the herbicide glyphosate in two conditions of temperature and photoperiod: winter $\left(12 / 8{ }^{\circ} \mathrm{C}\right.$ and $\left.10 / 14 \mathrm{~h}\right)$ and summer $\left(28 / 20{ }^{\circ} \mathrm{C}\right.$ and $\left.14 / 10 \mathrm{~h}\right)$, evaluated in 21 and 42 days after the application of the treatments (DAT) and reduction of dry mass from the aerial part (MSPA (\%)) in 42 DAT. UFSM, Frederico Westphalen-RS, 2013. 
Table 1 - Equations ${ }^{1 /}$ utilized to determine the necessary dose to obtain $50 \%$ of the control $\left(\mathrm{C}_{50}\right)$ or the reduction of $50 \%$ of the dry mass $\left(\mathrm{GR}_{50}\right)$ from the biotypes of Conyza bonariensis susceptible $(\mathrm{S})$ and resistant $(\mathrm{R})$ to the herbicide glyphosate. UFSM, Frederico Westphalen-RS, 2013

\begin{tabular}{|c|c|c|c|c|c|c|}
\hline Biotype & $\bar{A}$ & $\mathrm{~B}$ & $\mathrm{C}_{50}\left(\mathrm{~g} \mathrm{e} \mathrm{a} \mathrm{ha}^{-1}\right)$ & $\mathrm{R}^{2 \underline{2} !}$ & $\mathrm{FR}^{3 /}$ & $\mathrm{Itr}^{4 / 4}$ \\
\hline \multicolumn{7}{|c|}{$21 \mathrm{DAT}^{*}$} \\
\hline S-Winter & 84.01 & 38.71 & 71.71 & 0.94 & --- & 11 \\
\hline R-Winter & 52.52 & 1540.70 & 4040.21 & 0.98 & 56.34 & 7 \\
\hline S-Summer & 98.80 & 8.03 & 39.34 & 0.99 & --- & 9 \\
\hline R-Summer & 96.70 & 905.10 & 1524.29 & 0.96 & 38.69 & 10 \\
\hline \multicolumn{7}{|c|}{$42 \mathrm{DAT}$} \\
\hline S-Winter & 97.35 & 29.60 & 55.44 & 0.95 & --- & 12 \\
\hline R-Winter & 52.01 & 1350.34 & 3475.41 & 0.98 & 62.68 & 8 \\
\hline S-Summer & 99.28 & 6.78 & 37.96 & 0.99 & --- & 12 \\
\hline R-Summer & 99.12 & 352.74 & 832.74 & 0.99 & 21.94 & 7 \\
\hline \multicolumn{7}{|c|}{$42 \mathrm{DAT}$} \\
\hline S-Winter & 89.85 & 10.82 & 38.16 & 0.97 & --- & 11 \\
\hline R-Winter & 66.44 & 879.63 & 2281.38 & 0.97 & 59.78 & 8 \\
\hline S-Summer & 94.30 & 5.70 & 36.05 & 0.99 & --- & 11 \\
\hline R-Summer & 91.56 & 454.48 & 907.23 & 0.97 & 25.19 & 9 \\
\hline
\end{tabular}

${ }^{1 /}$ Sigmoidal equation $Y=a /\left(1+\exp \left(-\left(X-X_{50}\right)^{b}\right)\right)$, em que $X_{50=} G_{50}(p<0,05)$ ou $X_{50=} C_{50}(p<0,05)$. ${ }^{2} /$ Determination coefficient. ${ }^{3} /$ Resistance factor $=\mathrm{C}_{50} \mathrm{R} / \mathrm{C}_{50} \mathrm{~S}$ ou $\mathrm{GR}_{50} \mathrm{R} / \mathrm{GR}_{50} \mathrm{~S} .{ }^{4 /} \mathrm{Itr}=$ iteration number used to adjust the equation parameters. * Days after the treatment application.

control percentage with lesser doses than for those of the biotype R. The necessary dose to promote $50 \%$ of the control of C. bonariensis $\left(\mathrm{C}_{50}\right)$ was of 4040.21 and $71.71 \mathrm{~g}$ e.a. ha ${ }^{-1}$ for $\mathrm{R}$ and $\mathrm{S}$, respectively (Table 1 ). The resistance factor (FR) indicated, in 21 DAT and for the winter condition, that the biotype $\mathrm{S}$ is 56.34 times more sensitive to glyphosate than R. In the conditions that simulate summer, hugh temperatures and photoperiod with 14 hours of light, in 21 DAT it was observed control higher than $90 \%$ in the biotype $\mathrm{S}$, in a dose of 90 g e.a. ha ${ }^{-1}$, while for $\mathrm{R}$ the necessary dose to achieve a similar control was approximately 5,760 g e.a. ha-1 (Figure 1A). In this scenario, the $\mathrm{C}_{50}$ was 39.34 and $1524.70 \mathrm{~g}$ e.a. ha ${ }^{-1}$ for the biotypes $S$ and $R$, respectively, and the FR obtained was of 38.69 (Table 1).

Comparing the temperature and photoperiod conditions to the 21 DAT, it was observed that both control biotypes were superior to the summer conditions (V), when compared to the winter (I). Biotype $\mathrm{S}$ showed a higher percentage control than $\mathrm{R}$ in both conditions: I and V. Biotype $\mathrm{R}$ showed a reduction in its capacity of resisting glyphosate in condition $\mathrm{V}$, where it showed $\mathrm{C}_{50}$ of 1524.21 g e.a. ha ${ }^{-1}$, whilst for the condition I, the $\mathrm{C}_{50}$ was of $4,040.21 \mathrm{~g}$ e.a. ha $^{-1}$, resulting in FR of 38.69 e 56.34 in V and I, respectively (Table 1).

In the evaluation done in $42 \mathrm{DAT}$, it was verified a greater control of the biotype $S$ in comparison to $\mathrm{R}$, in the conditions $\mathrm{I}$ and $\mathrm{V}$ (Figure 1B). The FR observed in condition I was higher than the one in $\mathrm{V}$, with values of 62.68 and 21.94 for the biotypes S and R, respectively. Thus, the conditions of high temperature and prolonged photoperiod influenced negatively in the resistance of the biotype R. In this study, low temperatures and reduced photoperiod were not enough to reverse the resistance, disagreeing with Ge et al. (2011), that observed reversion when $C$. canadensis plants were submitted to these conditions, associating this effect to a lower activity from the tonoplast carriers responsible to the herbicide's sequestration in the vacuole, which becomes the plant behavior susceptible. A similar behavior was observed in Sorghum halepense and Lolium rigidum, that showed a significant reduction in the glyphosate resistance parameters, when resistant plants treated with the herbicide were cultivated under non ideal temperature conditions: $19{ }^{\circ} \mathrm{C}$ and $8{ }^{\circ} \mathrm{C}$, respectively (VILA-AIUB et al., 2013). 
The accumulation of the aerial part's dry mass (MSPA) observed in 42 DAT is in agreement with the visual control values obtained, in which the smallest doses of glyphosate were enough to inhibit the mass accumulation in the biotype $\mathrm{S}$ in both conditions of temperature and photoperiod, when compared to $\mathrm{R}$ (Figure 1C). The necessary doses to promote a reduction of $50 \%$ of the dry mass $\left(\mathrm{GR}_{50}\right)$ to the biotype $\mathrm{S}$ were 38.16 and 36.05 g e.a. ha ${ }^{-1}$ for $I$ and V, respectively. The biotype $R$ presented $\mathrm{GR}_{50}$ of 4312.24 for the winter conditions and 1090.84 for summer conditions, and FR of 2281.38 and 907.23, respectively (Table 1). The occurrence of variations in the resistance factors between the control visual variables (\%) and MSPA should be highlighted. Nevertheless, amplitude variations in the FR were also reported by Trezzi et al. (2011), that, while working with glyphosate resistant Coniza spp. plants, observed, to the same biotype, FR of 3.98 and 37.27 to the control variables in 21 DAT and dry matter, respectively. However, despite the variations in the FRs, all of them maintained themselves over 10, considered high, characterizing a high level of resistance (Vidal et al., 2007)

Herbicide resistant plants may produce new enzymes or increase the enzymes' activity, granting resistance (Werck-Reichhart et al., 2000). Nonetheless, the additional energy needed to produce these enzymes may reduce the energy allocated to the growth and reproduction in the absence of the herbicide or under stress caused by the environment (Vila-Aiub et al., 2009). Thereby, from the decrease in capacity to resist to high temperatures and prolonged photoperiod, one may deduce that the resistant biotype present the resistance mechanism linked to alterations in the target site, that is, the EPSPs enzyme, and not the vacuole sequestration.

\section{Resistance Mechanism - related to the active site}

The evaluation of the shikimate accumulation in Conyza bonariensis was done from the elaboration of the shikimate's standard curve (Figure 2A). The results of the shikimate accumulation observed for the
C. bonariensis biotypes showed interaction between the biotypes and the herbicide dose. The value of $\mathrm{R}^{2}$ was 0.97 and 0.98 , for $\mathrm{S}$ and $\mathrm{R}$, respectively, showing a satisfactory adjustment of the data to the model (Table 2).

From the equations, the values of glyphosate doses responsible for increasing in $50 \%$ the accumulation of shikimate $\left(\mathrm{AS}_{50}\right)$ to Conyza bonariensis were calculated. The equations, in turn, prove that the biotype $R$ has a differential behavior for increasing doses of the glyphosate herbicide.
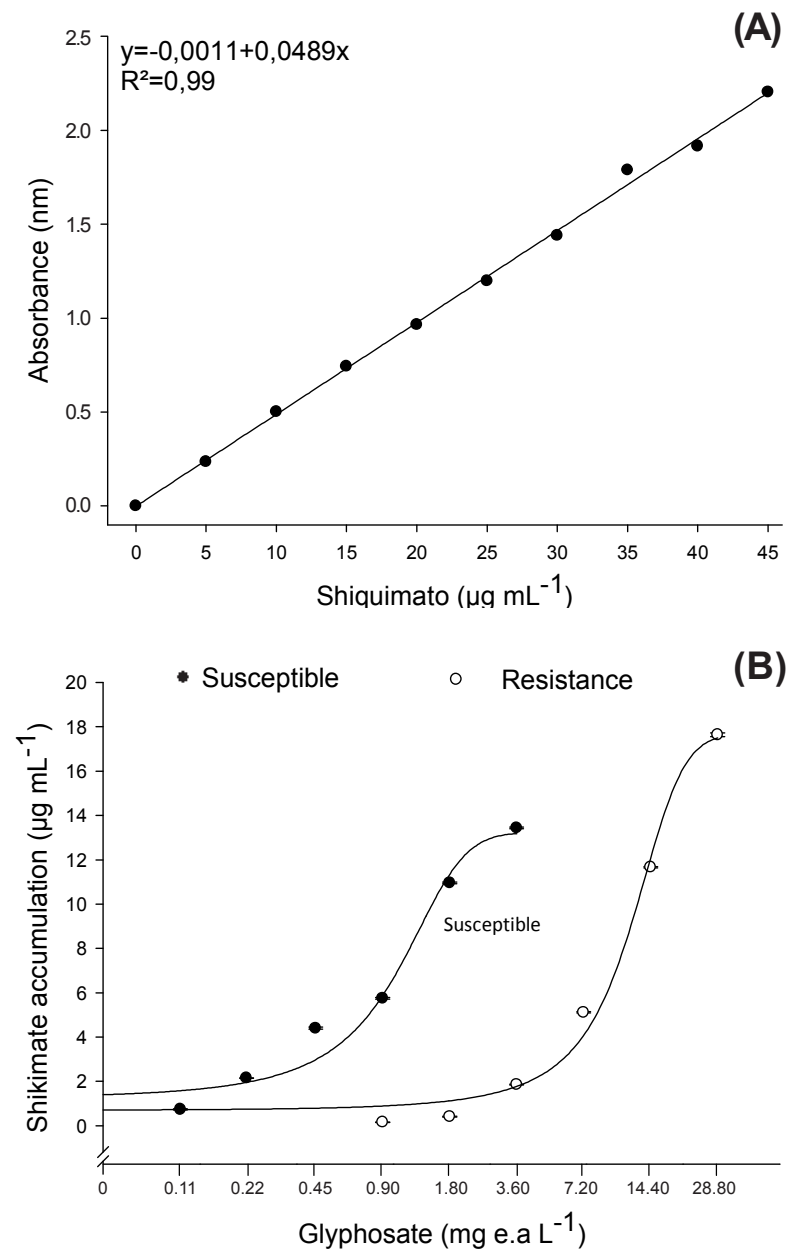

* The dots represent the average in the repetitions, and the vertical bars, the confidence interval.

Figure 2 - Standart curve of shikimate, $\mathrm{Y}=-0.0011+0.0489 \mathrm{x}$, $\mathrm{R}^{2}=0.99$ (A) and the accumulation of shikimate in Conyza bonariensis biotypes, susceptible (S) and resistant (R) to the herbicide glyphosate. UFPel, Pelotas-RS, 2013. 
Table 2 - Equation ${ }^{1 /}$ used to determine the necessary dose to increase in 50\% the shikimate accumulation $\left(\mathrm{AS}_{50}\right)$ in the Conyza bonariensis biotypes, susceptible (S) and resistant (R) to the herbicide glyphosate. UFPel, Pelotas-RS, 2013

\begin{tabular}{|c|c|c|c|c|c|c|}
\hline Biotype & $\mathrm{A}$ & $\mathrm{b}$ & $\mathrm{AS}_{50}\left(\mathrm{mg} \mathrm{e} . \mathrm{a} \mathrm{L}^{-1}\right)$ & $\mathrm{R}^{22}{ }^{2 /}$ & $\mathrm{FR}^{3 /}$ & $\mathrm{Itr}^{4 /}$ \\
\hline $\mathrm{S}$ & 13.22 & 0.44 & 1.00 & 0.97 & --- & 8 \\
\hline $\mathrm{R}$ & 17.64 & 3.64 & 11.58 & 0.98 & 11.58 & 8 \\
\hline
\end{tabular}

${ }^{1 /}$ Sigmoidal equation $\mathrm{Y}=\mathrm{a} /\left(1+\exp \left(-\left(\mathrm{X}-\mathrm{Xa}_{50}\right)^{\mathrm{b}}\right)\right)$, where $\mathrm{Xa}_{50=} \mathrm{AS}_{50}(\mathrm{p}<0,05)$. ${ }^{2} /$ Determination coefficient. ${ }^{3 /}$ Resistance factor $=\mathrm{AS}_{50} \mathrm{R} /$ $\mathrm{AS}_{50} \mathrm{~S} .{ }^{4 /} \mathrm{Itr}=$ number of iterations used to adjust the equation parameters.

The shikimate curve shows significant rise in the accumulation of this metabolite for both biotypes of hairy fleabane, due to the increase of the herbicide dose (Figure 2B). However, for the biotype $\mathrm{S}$, the increase in the control level was verified in lower dose and with greater intensity than in the biotype R. The necessary dose to promote an increase of $50 \%$ in the shikimate accumulation in C. bonariensis $\left(\mathrm{AS}_{50}\right)$ was of 11.58 and $1.0 \mathrm{mg}$ e.a. $\mathrm{L}^{-1}$ for the biotypes $\mathrm{R}$ and $\mathrm{S}$, respectively (Table 2). The FR indicated that the biotype $\mathrm{S}$ was 11.58 times more sensitive to glyphosate than R. However, the resistance level observed for the shikimate accumulation was below the one verified in the studies of dose curve in varied conditions of temperature and photoperiods (Resistance Mechanism - not related to active site), indicating the biotype $\mathrm{R}$ a possible action of a complementary resistance mechanism.

The accumulation of differential shikimic acid after the treatment with glyphosate may occur when the biotypes are different between each other in sensitivity for the herbicide, for differences in the target site (Powles and Preston, 2006). A reduction in the accumulation of shikimate was also demonstrated by Nol et al. (2012) in C. canadensis glyphosate resistant biotypes in which, for the most part of the herbicide (3.6 mg e.a. $\mathrm{L}^{-1}$ ) an accumulation of approximately 28 times lower was obtained in comparison to the susceptible biotype, characterizing resistance by change in the susceptibility of the EPSPs enzyme. Thereby, it may be inferred that the EPSPs enzyme in the biotype $\mathrm{R}$ presented a lower affinity to the glyphosate molecule, which enabled the enzyme to stay active, even in the presence of high doses of herbicide. Thus, there is no shikimate accumulation and the production of aromatic amino acids (phenylalanine, tyrosine and tryptophan) was kept in its metabolic route, enabling the plant development after the treatment with herbicide. It has been observed a lower accumulation of shikimate in population of Lolium rigidum resistant to glyphosate and, subsequently, through the sequencing of the gene which codifies the EPSPs, it was proven a mutation in the 106 loci, where a proline was exchanged by a threonine (Wakeliln and Preston, 2006). This way, it is possible to correlate a change in sensitivity in the EPSPs enzyme to glyphosate from the evaluation of shikimate accumulation.

In a study with susceptible and resistant Digitaria insularis biotypes, a difference in the accumulation of shikimate was not verified until 72 hours after the glyphosate application, indicating that the EPSPs enzyme did not present differential susceptibility to the herbicide (Carvalho et al., 2012). However, studies with $C$. canadensis show that the amount of shikimic acid decreases in plants submitted to glyphosate treatment after 3-4 days of the herbicide application, indicating an action of the resistance mechanism not related to the target enzyme, but to the differential metabolism and reduced translocation (Mueller et al., 2008; Chodová et al., 2009; González-Torralva et al., 2012).

The mechanism that possibly is responsible for the resistance in the C. bonariensis biotype in question apparently is not related to the herbicide sequestration to the vacuole via tonoplast transporters. This may be inferred because, under low temperature and reduced photoperiod conditions, the resistance was maintained, disagreeing of that which was observed by Ge et al. (2011). These authors report that, in 
similar temperature and photoperiod conditions, the resistance reversion to glyphosate in hairy fleabane that presented the herbicide sequestration by the vacuole as a resistance mechanism mediated by tonoplast transporters. Nevertheless, the resistance mechanism seems to be related to an alteration in the target site, where the EPSPs enzyme activity in the resistant biotype was kept elevated even after exposed to glyphosate doses capable to inhibit the enzyme activity in the susceptible biotype. However, the resistance in $C$. bonariensis may not be the result of the enzyme insensitivity by itself, but yet of its overexposure, or even because of the action of more than one resistance mechanism, demanding complementary studies for a full understanding.

\section{ACKNOWLEDGEMENTS}

To the Fundação de Amparo à Pesquisa do Estado do Rio Grande do Sul - FAPERGS, for the funding of this research (Projeto Auxilio RecémDoutor - ARD,Edital 01/2011, Processo no 11/ 1989-0). To Professor Ilsi Iob Boldrini, from Instituto de Biociências of the Departamento de Botânica in the Universidade Federal do Rio Grande do Sul (UFRGS), Porto Alegre-RS, for the confirmation in the identification of the species Conyza bonariensis.

\section{REFERENCES}

Carvalho L.B. et al. Pool of resistance mechanisms to glyphosate in Digitaria insularis. J Agric Food Chem. 2012;60:615-22.

Chodová D. et al. Horseweed with reduced susceptibility to glyphosate found in the Czech Republic. J Agric Food Chem. 2009;57:6957-61.

Feng P.C.C. et al. Investigations into glyphosate-resistant horseweed (Conyza canadensis): retention, uptake, translocation, and metabolism. Weed Sci. 2004;52:498-505.

Ferreira E.A. et al. Glyphosate translocation in hairy fleabane (Conyza bonariensis) biotypes. Planta Daninha. 2008;26:637-43.

Ge X. et al. Glyphosate-resistant horseweed made sensitive to glyphosate: low-temperature suppression of glyphosate vacuolar sequestration revealed by ${ }^{31} \mathrm{PNMR}$. Pest Manage Sci. 2011;67:1215-21.
Ge X. et al. Rapid vacuolar sequestration: the horseweed glyphosate resistance mechanism. Pest Manage Sci. 2010;66;345-8.

González-Torralva F. et al. Two non-target mechanisms are involved in glyphosate-resistant horseweed (Conyza canadensis L. Cronq.) biotypes. J Plant Physiol. 2012;169:1673-9.

Henry W.B. et al. Shikimate accumulation in sunflower, wheat, and proso millet after glyphosate application. Weed Sci. 2007;55:1-5.

Koger C.H. et al. Role of absorption and translocation in the mechanism of glyphosate resistance in horseweed (Conyza canadensis). Weed Sci. 2005;53:84-90.

Lebaron H.M., Gressel J. Herbicide resistance in plants. New York: Wiley-Interscience, 1982. 401p.

Mueller T.C. et al. Shikimate accumulation in nine weedy species following glyphosate application. Weed Res. 2008;48:455-60.

Nandula V.K. et al. Glyphosate tolerance mechanism in Italian Ryegrass (Lolium multiflorum) from Mississippi. Weed Sci. 2008;56:344-9.

Nol N. et al. Shikimate leaf disc assay for early detection of glyphosate resistance in Conyzacanadensis and relative transcript levels of EPSPS and ABC transporter genes. Weed Res. 2012;52:233-41.

Powles S.B., Preston C. Evolved glyphosate resistance in plants: biochemical and genetic basis of resistance. Weed Technol. 2006;20:282-9.

Powles S.B., Yu Q. Evolution in action: plants resistant to herbicides. Ann Rev Plant Biol. 2010;61:317-47.

Service R.F.A. Growing threat down on the farm. Science. 2007;316;1114-7.

Shaner D.L. et al. A rapid in vivo shikimate accumulation assay with excised leaf discs. Weed Sci. 2005;53:769-74.

Trezzi M.M. et al. Resistência ao glyphosate em biótipos de buva (Conyza spp.) das regiões oeste e sudoeste do Paraná. Planta Daninha. 2011;29;1113-20.

Vidal R.A. et al. Definindo resistência aos herbicidas. Rev Plantio Direto. 2007;100:18-19.

Vila-Aiub M.M. et al. Fitness costs associated with evolved herbicide resistance alleles in plants. New Phytol. 2009; 184:751-67.

Planta Daninha, Viçosa-MG, v. 34, n. 3, p. 555-564, 2016 
Vila-Aiub M.M. et al. Glyphosate resistance in Sorghum halepense and Lolium rigidum is reduced at suboptimalgrowing temperatures. Pest Manage Sci. 2013;69:228-32.

Wakelin A.M., Preston A.C. Target-site mutation is present in a glyphosate resistant Lolium rigidum population. Weed Res. 2006;46:432-40.
Werck-Reichhart D. et al. Cytochromes P450 for engineering herbicide tolerance. Trends Plant Sci. 2000;5:116-23

Yu Q. et al. Glyphosate, paraquat and ACCase multiple herbicide resistance evolved in a Lolium rigidum biotype. Planta. 2009;225:499-513. 